\title{
Culturador
}

\section{Entrevista al Teólogo Leonardo Boff sobre lglesia, ecumenismo y protección de la Creación}

Recibido: 22 de febrero de 2013 / Aprobado: 15 de mayo de 2013

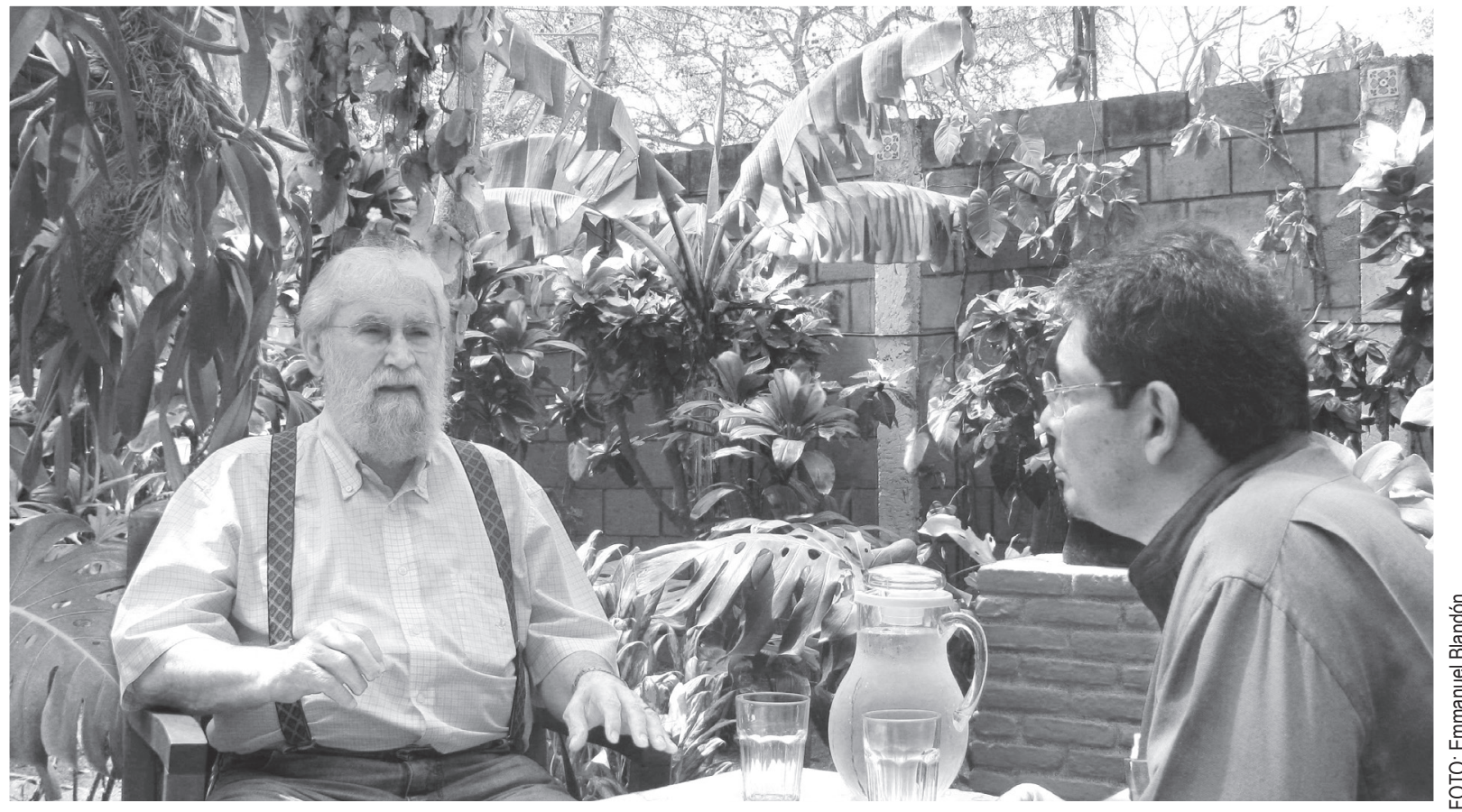

Leonardo Boff entrevistado por Denis Torres, Director del IMLK-UPOLI.

\section{RESUMEN}

El teólogo ecuménico y mundialista Leonardo Boff, desde su perspectiva eco-teológica aborda temas contemporáneos de la más alta relevancia: el nuevo Papa Francisco, de quien espera actúe como Jesuita ante las reformas que demanda la Curia y como franciscano ante el pueblo; la vigencia de la Teología de la Liberación, la esperanza de salvación de la Madre Tierra como obra de las manos de Dios.

Palabras clave: Espiritualidad, ecumenismo, Madre Tierra, poder, Naciones Unidas.

\section{ABSTRACT}

The ecumenical theologian Leonardo Boff from his eco-theological perspective tackles some contemporary topics of the highest importance: the new Pope Francisco, who hopes to act as a Jesuit before the reforms demanded by the Curia and as a Franciscan before the people, the relevance of the Liberation Theology, the hope of salvation of Mother Earth as a work of God's hands.

Key words: Spirituality, Ecumenism, Mother Earth, power, United Nations.

\section{A manera de introducción:}

Leonardo Boff, es uno de los teólogos, ecólogos, filósofos más importantes a nivel contemporáneo, responde a esas personalidades que antes se les llamó Humanistas, de esas figuras que dominan muchos ámbitos del conocimiento. Vamos a trabajar en una entrevista, tocando temas sensibles: la iglesia, la temática medioambiental, el factor religioso, la espiritualidad y también vamos a cerrar, por ser nuestra materia prima de trabajo con el paradigma de la Cultura de la Paz.

Para nosotros es un gran honor tenerlo entre nosotros en Nicaragua y que haya tenido la deferencia de brindar esta entrevista.

\footnotetext{
* Teólogo, filósofo y ecologista brasileño.
} 
Quisiéramos comenzar con los últimos acontecimientos que todavía están en las primeras planas de los medios de comunicación sobre la elección del nuevo Papa. Realmente, para todos ha sido una gran sorpresa y no deja de generar un sentimiento de esperanza, en un momento en que a nivel mundial hay tantos problemas que necesitan de una iglesia que recupere su papel profético.

Tratándose de quien se trata, es importante conocer su opinión, sus valoraciones sobre la elección de este nuevo Papa, Francisco, que nos habla de que la iglesia no sólo debe identificarse con los pobres, sino ser pobre, pero también desde la opción por los pobres, nos habla de la necesidad de la lucha contra la corrupción, de la paz fundamentada en la justicia. Él afirma que mientras exista un estado de pobreza no se puede hablar de una paz integral, sostenible y duradera.

\section{Nuevo Papa, iglesia y ecuminismo}

Denis Torres ${ }^{1}$ : Doctor Boff, la elección del nuevo Papa... ¿Augura cambios significativos en la iglesia católica? Tomando en cuenta dos factores que han destacado en relación al Papa Francisco: Apela a una iglesia pobre y al lado de los pobres; habla de volver al Concilio Vaticano II y la lucha contra la corrupción.

Leonardo Boff: Para nosotros teólogos, la elección de Francisco es una bendición, porque bajo los dos anteriores Papas, la teología no tenía libertad. No hay que olvidar que el Cardenal Ratzinger, y después como Papa persiguió, condenó a más de 130 teólogos, los mejores de cada país, entonces, no se hacía teología en libertad, porque todo lo que es creativo, que se confronte con la realidad, exige libertad y espíritu de creatividad, eso no había en la Iglesia. Tenía que encuadrarse en los esquemas sociales, el pensamiento único, no solamente en la política o en la economía, también en la Iglesia, el pensamiento único que viene de Roma.

Bueno, con el Papa Francisco, dos cosas me parecen fundamentales: primero, que es el primer Papa que viene del tercer mundo y en el tercer mundo vive el $60 \%$ de todos los católicos, es decir, la Iglesia Universal se ha dado cuenta que la vitalidad y la fuerza, incluso en términos numéricos ya no está en el primer mundo, allí vive solamente el $24 \%$ de los católicos. Están en América Latina el 42\%, está en África, está en Asia y esas iglesias ya no son iglesias espejo de la iglesia de Europa, son iglesias puentes porque ensayan un diálogo nuevo con la cultura, inventan sus formas litúrgicas, tienen sus propias teologías, que por lo menos de América Latina tenemos tantos. Entonces esos Papas vienen de una Iglesia donde hay vitalidad, donde no hay crisis como en el centro de la Iglesia.

$\mathrm{Y}$ en segundo lugar es el nombre, Francisco. Francisco es más que un nombre, es un proyecto de Dios, porque Francisco se convirtió de joven, de la burguesía clasista, al escuchar la palabra que venía de un crucifijo de la iglesia en San Damián. Francisco reconstituye una Iglesia que está en ruinas. De ahí empezó él a reconstruir una Iglesia que estaba en ruinas, la Iglesia material, que hasta hoy existe en Asís, pero inmediatamente se dio cuenta que no se trataba de construir un edificio, se trataba de reformar la Iglesia, la Cristiandad que estaba realmente en ruinas, bajo Inocencio III que fue el Papa más poderoso de toda la Iglesia, porque bajo su regencia se unieron los dos polos: el imperio y el sacerdocio. El poder temporal y el poder sacerdotal y toda Europa estaba sometida al Papa, incluso Rusia.

Entonces era el apogeo supremo, nunca la Iglesia llegó a tanta gloria y tanto apogeo y en ese contexto aparece San Francisco tomando alternativas: una iglesia de las bases, de los pobres, se junta con los leprosos, predica en las lenguas populares, él hablaba francés, por su madre francesa, hablaba italiano popular y no hace una crítica verbal contra esa iglesia del poder, pero sigue un camino de una iglesia de pobres, sin poder y creando ya un movimiento enorme que se agrega al gran movimiento que estaba arrastrando en todo el norte de Europa, que era el movimiento de los pauperistas, los valdenses, los pobres de Lion, de los pobres de Florencia y dentro de eso estaba el movimiento de San Francisco.

Entonces, cuando el Papa Francisco elige el nombre Francisco, ya pienso que es otra Iglesia y lo ha mostrado concretamente en el primer momento que aparece en público, no aparece con esa boceta italiana, ese pequeño manto que le cubre los hombros, que era típico del poder imperial de los emperadores romanos. Dijo al secretario, el carnaval se terminó, lléveselo. No aceptó la cruz de oro del Papa, que es de oro con joyas, la relegó y vino con su cruz de hierro,

* Director Instituto "Martin Luther King", Universidad Politécnica de Nicaragua (UPOLI) 


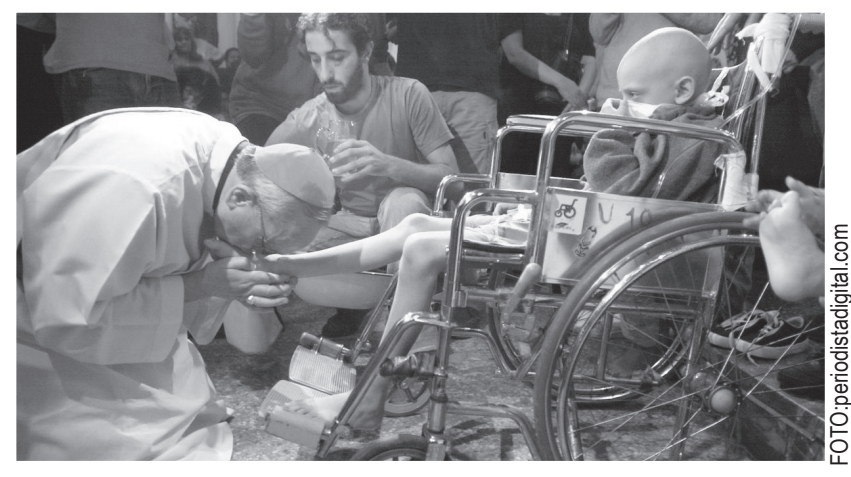

sin ninguna señal de poder, se inclina hacia el pueblo y pide algo importante, eso tiene una dimensión teológica decisiva, pide que el pueblo bendiga al Papa y solamente después él va a bendecir al pueblo. ¿Qué significa? Que la centralidad la tiene el pueblo de Dios. La jerarquía, el Papa son servidores del pueblo de Dios. Y al día siguiente, es un Papa que va a pagar sus cuentas, va al pequeño hotel, pagó los 96 Euros por día, recogió sus cosas y su maletín y se marchó al Vaticano. Eso es impensable para La Curia, para un cristiano que tiene esa veneración del Papa, impensable. Y al domingo siguiente, días antes, él no se anuncia Papa, se anuncia Obispo de Roma.

Él, cuando pide rezar por el Papa Emérito, por Ratzinger, lo dice: vamos a rezar por el Obispo Emérito de Roma, Ratzinger. Eso rescata la más vieja tradición del primer milenio, que el Obispo de Roma es el primero entre iguales, no es Papa, es Obispo y articula las demás iglesias, pero no por vía jurídica y él lo dice muy bien, quiere ordenar su pontificado en la caridad, no en el poder político. Y el domingo siguiente va a la parroquia del Papa, celebra su misa como párroco y al terminar la misa no se va a la sacristía como todos los párrocos, se va a la puerta de la iglesia, charla con uno, con la viejita, con todos, los abraza, como un párroco y eso para mí es enseñar que la iglesia va a inaugurar el tercer milenio.

El milenio de una iglesia, red de comunidades, una iglesia que renuncia al poder, que está en la tradición de Jesús, que fue un pobre, desposeído y eso yo creo que hay que saludarlo como algo importante para la iglesia, para las iglesias, pero también para la humanidad, porque queramos o no, el Papa es el signo de lo sagrado más importante de occidente, tiene esa figura, pero él va a despojarse de eso, o sea tener un liderazgo, moral, espiritual y no político, no meramente moralizante, sino alguien que suscita esperanza, suscita humanidad, fraternidad.
Denis Torres: ¿En la Iglesia Católica tiene un peso determinante el Personaje frente a la estructura? ¿Cuáles son los alcances y limites del poder del Papa?

Es como pensar en Obama, con toda una gran esperanza que causó, con sus promesas de reconciliación con el mundo y al interior de la sociedad norteamericana, pero es evidente que los grandes poderes, fáticos y de todo tipo, han hecho "prisionero" al hombre en la Casa Blanca.

Leonardo Boff: Bueno, yo creo que hay que subrayar que Papa hay uno solo, entonces hay una singularidad, es un arquetipo de lo sagrado, de otra dimensión, no de los poderes económicos y políticos. Él tiene que ver con una herencia de Jesús, algo extremadamente espiritual, que nadie puede ser contra Jesús, podemos traicionarlo, pero la figura de Jesús, que de una manera él representa, es emblemática y atrae a mucha gente. Por otra parte, hay la vantajas de la estructura piramidal de la iglesia. A mí no me gusta esta estructura porque no tiene nada de evangelio y es una monarquía absolutista. El canon 331 lo dice claro, que el Papa tiene el absoluto poder, ordinario, ilimitado, sobre toda la iglesia, sobre cada uno de los fieles. Entonces, si un Papa como Francisco, que ahí no puede ser franciscano, tiene que ser jesuita y dice voy a utilizar ese poder para limpiar La Curia, lo que estaría difícil, porque existen verdaderos pecados, con preceptos, con fundamentos cristianos violados, como el sexto mandamiento, en particular lo relacionado a la pederastía que escandalizó enormemente. Entonces, mi interpretación es que él va a ser un jesuita.

Uno, para limpiar la Iglesia, de la manera más directa de limpiarla, es decir, sustitución, llamar gente de otras partes de la Iglesia, que no están metidas en ese tinglado, en esa relación de poder y a mi juicio y es la opinión de muchos vaticanólogos, de los que entienden el Vaticano, que la manera más fácil sería descentralizar La Curia y por eso alejar a las personas, porque no hay ninguna razón que el Dicasterio, como Ministerio de Misiones se quede en Roma, puede estar tranquilamente en otro lugar, por ejemplo, el Ministerio de Derechos Humanos y Justicia puede estar en América Latina, el Ministerio de Diálogo con Culturas puede estar tranquilamente en África y algo con las iglesias puede estar en Ginebra, junto al Consejo Mundial de Iglesias; y hoy con las redes sociales, por la internet, por Skype, por el Messenger, se puede tener inmediato contacto y ahí, esos ministerios, dicasterios tendrían contacto directo con las religiones y no burocráticos, mediante relatores de papeles; y ahí van 


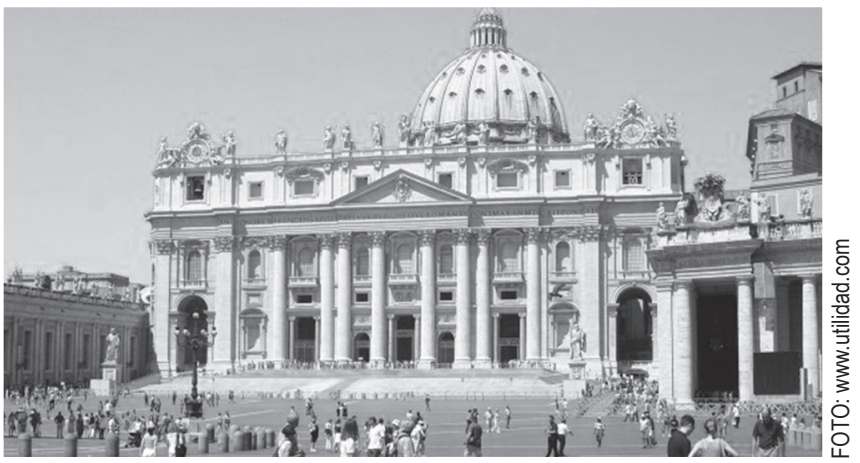

a descubrir que hay santidad en las religiones, que hay culturas de grandes bellezas en América Latina, con nuestras culturas latinoamericanas, andinas y de los pueblos originarios, con grandes valores éticos, espirituales, con un sentido natural de teología.

Entonces, esa sería una forma posible, y yo espero que él actúe como jesuita, porque un jesuita tiene una cabeza muy bien hecha, muy inteligente, él es un ícono de la modernidad, de la razón estratégica. Ahí él no tiene que ser Francisco porque Francisco es dulzura, ternura, comprensión, ahí hay que ser duro, porque se trata del crimen que se ha cometido $\mathrm{y}$ eso tiene que ser llevado a los tribunales, las personas tienen que ser arrestadas para que no sigan escandalizando a la iglesia y quitando la mínima credibilidad que el mensaje de Jesús pide.

Denis Torres: ¿Desde el punto de vista del ecumenismo, qué se podría esperar del nuevo Papa y la relación con las otras religiones del mundo?

\section{Leonardo Boff: Yo creo que el Papa Francisco} tiene que reinventar el ecumenismo, porque el Cardenal Ratzinger, después Papa Benedicto XVI, destrozó 50 años de ecumenismo. Escribió un documento en el 2000: Dominus Iesus, que es uno de los documentos más retrógrados y más dañinos a la Iglesia. ¿Por qué? Porque resucita la vieja idea medieval: que fuera de la Iglesia no hay salvación, y de cara a las demás iglesias dice: no son iglesias. Tiene elementos eclesiales, porque ha ofendido a todas las iglesias. A las religiones dice: todas ellas están en peligro de salvación, porque no pertenecen a la iglesia. Entonces, repetir en el siglo XXI esa típica doctrina, yo diría que es casi una blasfemia contra el Espíritu Santo, destrozó todo el ecumenismo.

Me acuerdo porque yo estaba dando clases en Heidelberg, Alemania, los Obispos Luteranos se reunieron y me pidieron que expusiera de manera teológica, el documento Dominus Iesus, porque se sentían muy humillados y yo lo expuse, mira, eso no representa el Concilio Vaticano II, no representa la mentalidad de la Iglesia Universal, es la teoría personal de un Cardenal que utiliza su poder de Cardenal para redactar un documento sin consultar a sus colegas. El Cardenal Walter Kasper, que era el encargado del diálogo con las religiones, él mismo me lo dijo, que no sabía de nada del documento y de repente sale publicado, ¿Cómo así? ¡Es un golpe! Él sabía cómo había luchas de poder, unos contra otros.

Entonces, yo creo que el Papa Francisco tiene que resucitar el ecumenismo, él como Cardenal en Buenos Aires tenía un diálogo muy bueno con los judíos, con los luteranos, con las demás iglesias, porque para él lo esencial no es tanto la doctrina, y a eso hay que prestarle atención, es un tipo Juan XXIII que como teólogo era muy convencional, muy conservador, que tiene sus devociones como el campesino nuestro, pero era un Pastor que sentía las necesidades del mundo, las tendencias de la cultura y veía en todo eso manifestaciones del Espíritu, porque el Espíritu nos hace una iglesia tan humilde, el Reino no está encapsulado en la iglesia.

\section{El Reino es la política de Dios en toda la realidad, en todo el mundo y los cristianos tienen que ver que el Reino sea realizado donde hay justicia, donde hay derechos, donde hay Cultura de Paz, ahí están los bienes de verdad, ahí está el Espíritu. El Espíritu que llega siempre antes del misionero, porque llega donde hay amor, donde hay compasión y no se necesita a un} misionero para eso.

Entonces, yo creo que este Papa, y ahí si se da tipo San Francisco. San Francisco fue a las cruzadas y quiso hablar con el Sultán, no querían dejarlo hablar de manera alguna. Al final rompió las trincheras, fue a encontrarse con el Sultán, se tomó 15 días con él, rezando juntos, no intentando convertirse el uno al otro, incluso al volver asumió algo de la teología del Sultán, que todos los musulmanes empiezan la oración: "Altísimo Omnipotente Señor". Francisco a 
partir de eso, todas las oraciones empieza "Altísimo Omnipotente y buen Señor", va al Papa y le dice que los musulmanes no son la encarnación del diablo, son personas muy piadosas, más piadosas que los cristianos, tenemos que respetarlos, tenemos que amar a nuestros enemigos, hay que cancelar las Cruzadas y los Papas tan imperiales, no lo escucharon.

Entonces San Francisco siguió el Camino del Señor abierto al diálogo, porque en el fondo en el fondo lo que necesitamos hoy en el mundo no son ni iglesias, ni religiones, ya existen ahí, las iglesias $\mathrm{y}$ religiones son fuentes de espiritualidad y hay espiritualidad en la humanidad.

La espiritualidad es

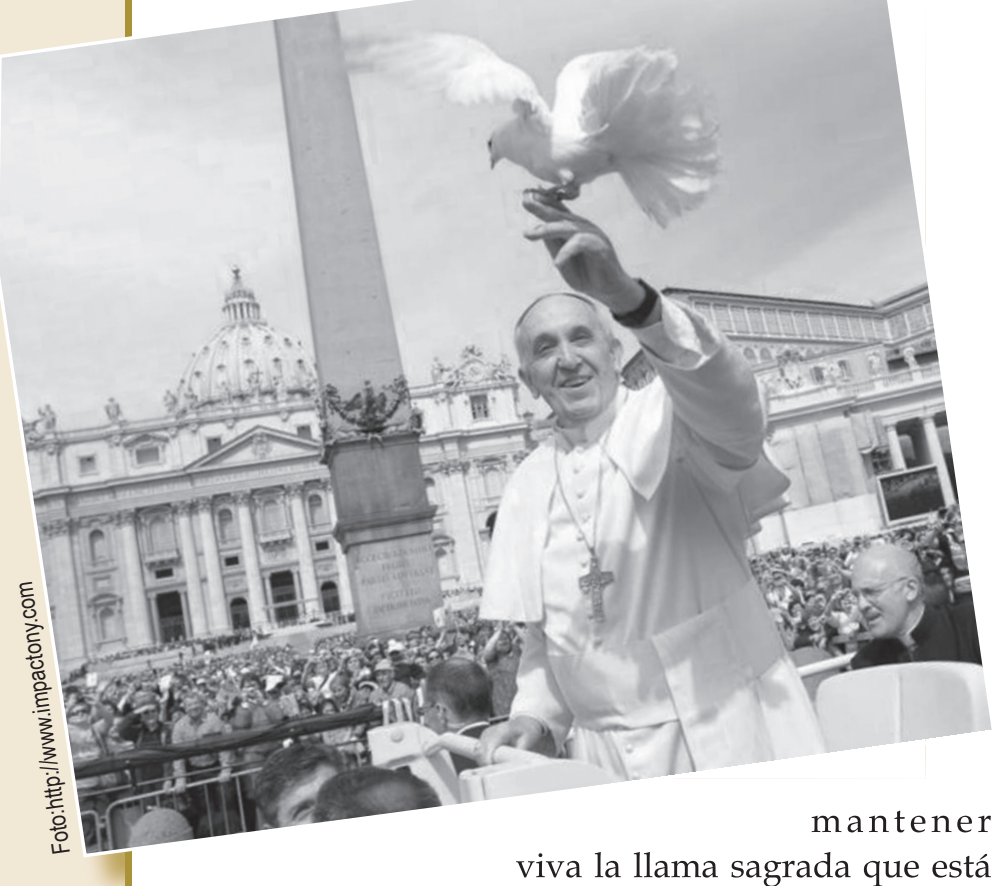

dentro de cada persona, la llama para valores más altos, para la compasión, para el amor y todos tienen algo de eso dentro de sí. La función de las religiones es mantener vivo eso, dar un cuadro para que se pueda desarrollar, y a él, yo lo conocí como teólogo, en un encuentro de espiritualidad en 1971 en el Colegio Mayor de San Miguel, donde él fue profesor allí. Una excelente charla sobre espiritualidad, es su especialidad, como teólogo, la espiritualidad y vive esa espiritualidad sencilla, jamás utilizando el coche, siempre en bus o en metro, andando a pie solo, no viviendo en el palacio sino en un pequeño apartamento donde se cocina su propia comida, vive en una extrema sencillez, es la persona llamada para inaugurar la iglesia del tercer milenio y sumar fuerzas para que la espiritualidad de la humanidad no se ahogue, porque si se ahoga el Espíritu, entonces si vamos al encuentro de la muerte.

Denis Torres: ¿Cómo entonces pensar el papel de, tanto la Iglesia institucional, como la Iglesia dispersa, para dijéramos, acompañar, brindar un cierto acompañamiento a toda esta etapa inaugural de una nueva espiritualidad, de un nuevo dinamismo en la iglesia, de cambios? ¿Qué papel nos cabe a nosotros que estamos un poco fuera?

\section{Leonardo Boff: Creo que cabe acoger eso} como un don, que sea del universo, que sea de la historia, para nosotros un don del Espíritu, porque es algo bueno que ocurrió en la humanidad, porque la humanidad sufre de referencias paradigmáticas, no hay líderes políticos, todos son formados en las escuelas de administración, administran los capitales, no administran nada, administran la economía, entonces no hay figuras tipo Gandhi, tipo de Gaulle, Adenauer, no hay.

Había, Juan Pablo II, a pesar de ser más conservador, populista, gran actor, pero era una referencia y todos se sentían un poco huérfanos, les falta la figura de un gran padre, un padre que confiere seguridad, el que apunta hacia un camino, y de repente aparece uno, del fin del mundo y tiene esa figura simpática de un gran padre, casi un abuelo, que inspira esperanza, confianza, esa confianza, porque es buena para la humanidad, los cristianos, no necesitan teólogos, Papas teólogos, para eso hay millares de teólogos en las iglesias evangélicas, en la Iglesia Católica, ellos hacen teología, lo que se necesita es un Pastor, una persona buena, que sienta los problemas concretos del pueblo, que tenga una palabra para animar, suscitar la esperanza, de no hacer peleas y atacar a los musulmanes porque son violentos, los judíos porque castigan a los palestinos, las mujeres porque quieren ser sacerdotes. Ese Papa, Benedicto XVI, cometió muchos errores de gobierno, no sabía gobernar.

Yo lo conocí porque fui alumno de él. Es una persona extremadamente tímida, excelente investigador, teólogo, pero pésimo Papa, porque no entusiasma a nadie, no tiene una mirada amorosa, en absoluto, no tiene gestos que animen, y el Papa Francisco sí tiene, no hizo una teatralización, nada, se dejó mirar, apareció blanquito allí, saludó una única vez, tranquilo, yo diría casi asustado mirando al pueblo, porque fue un susto para él mismo seguramente, pero 
entendió que dentro de una crisis de iglesia, y él lo reveló, que el compañero que estaba al lado que era el Cardenal Claudio Hummes de Brasil, que es un gran amigo de él, franciscano, le sopló al oído, “tienes que hacerte como San Francisco, la Iglesia estaba en ruinas como está ahora y tienes que ser un San Francisco que va a reconstituir la iglesia" y dice, entonces mi nombre será Francisco, a pesar de ser jesuita. Podría haber sido Francisco Javier, el gran misionero y sería un gran nombre. No, Francisco de la humildad, de la sencillez, la renuncia a toda esa pompa y gloria.

Yo no me sorprendería que él vaya a abolir todos esos actos palaciegos, esos títulos de nobleza, que tanto escandalizan a los cristianos que leen la Biblia, que ven a un Jesús pobre que no sabía dónde poner la cabeza y dice, eso no tiene nada que ver con la herencia de Jesús, pero tiene que ver todo con los palacios, ese tipo de Papa palaciano está más cerca del palacio de Herodes que de Belén, donde nació Jesús y él quiere estar allí donde Jesús mostró su vulnerabilidad de niño y

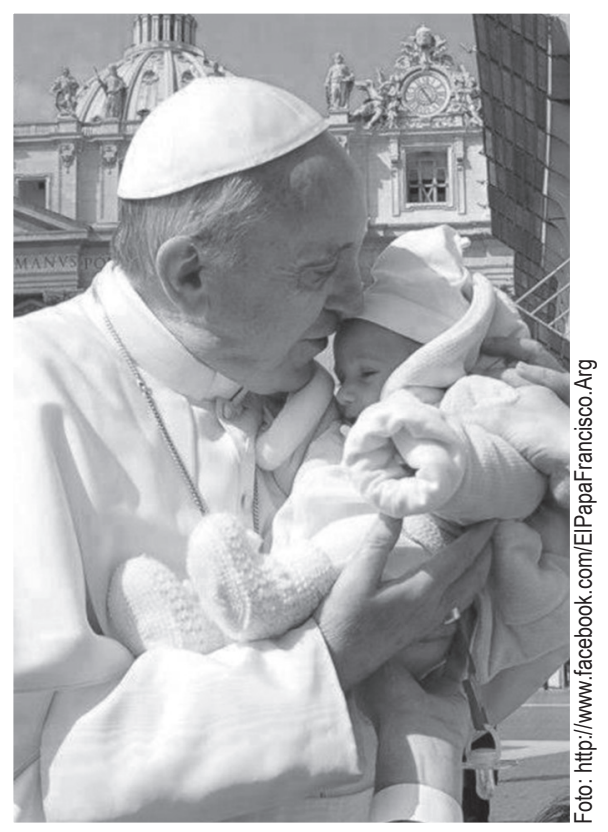
vivió pobre en este mundo y personalmente da un ejemplo de despojamiento, de despojo y de una profunda pobreza.

Denis Torres: ¿Cuál es su valoración, tal vez puede haber una pregunta, después de seguir a las otras, sobre el estado actual del ecumenismo en el mundo?

Leonardo Boff: Yo veo dos dimensiones. Si miramos el ecumenismo oficial, prácticamente está muerto por culpa del Vaticano. Primero, que no se asocia al Consejo Mundial de Iglesias y él se considera la única iglesia verdadera y representante de Cristo; las demás tienen elementos eclesiales, son decadencia de iglesia, pero la única Iglesia de Cristo subsiste en la Iglesia Católica Apostólica Romana, y eso termina todo diálogo. Si yo voy a hablar con musulmanes y les digo, él les dice: yo Papa, tengo toda la verdad y soy infalible; pues se acabó el diálogo, porque él habla de que él tiene toda la verdad y todavía infalible, entonces no tiene sentido.

Entonces, ese tipo de diálogo nunca resultó bien por culpa de la Iglesia Católica, por su arrogancia, por su insistencia de ser la única Iglesia. Pero, hay otro ecumenismo que aquí en América Latina tiene protagonismo, que es el ecumenismo de Misión, que en la Misión estamos todos juntos. Cuando vamos a ocupar una tierra que está sin cultivar en Brasil, vamos todos juntos, yo de franciscano con mi hábito, los bautistas, luteranos, de varias iglesias, porque estamos sirviendo a la justicia, salvando vidas, la opción es vida y vida en abundancia. La referencia común es Jesús y el evangelio y allí vamos juntos, y las doctrinas, pues eso que lo discutan los europeos, ellos son los teólogos. Nosotros estamos aquí en el seguimiento de Jesús, inspirados por el Reino y sirviendo a los más pobres.

Hay un vasto ecumenismo en América Latina, de maravilla. Yo hablo de mi país, porque lo conozco un poco más. Por ejemplo todo el trabajo con los indígenas que hace la Iglesia Católica, Luterana, Bautista y las demás, hacemos juntos una gran articulación; la pastoral de los afrodescendientes, primero, respetar sus religiones, apoyarlos, los que son católicos para que tengan una formación mejor, puedan reinventar sus ritos, su manera de ser, con las mujeres; la pastoral de niños, la pastoral de las mujeres, juntos, para que las mujeres tengan prominencia y se sientan con su protagonismo en la iglesia.

Ese ecumenismo de Misión, para mí es el verdadero ecumenismo, porque es el que Dios quiere, porque es una práctica de caridad, solidaridad, era esto lo que Jesús quería y porque al final, yo digo, no encuentro malo que haya varios tipos de iglesias, porque ninguna iglesia puede tener la pretensión de asimilar toda la riqueza del misterio de Jesús, sería demasiada pretensión.

Entonces, la herencia de Jesús es representada por varias iglesias que digo yo, por deducción, por ejemplo, si yo quiero saber de Biblia yo voy con los protestantes, ellos cultivan la Palabra de Dios, los católicos saben poco de Biblia, van al Catecismo; si yo 
quiero saber cómo hacer grandes celebraciones, me voy a la Iglesia Ortodoxa, fantásticas celebraciones; si yo quiero saber cómo se aplica el evangelio en las bases con los pueblos, voy a un Círculo Bíblico que es ecuménico, vamos a compartir páginas de la Biblia, páginas de la realidad y se comparan las dos y se sacan decisiones para la práctica, es ecuménico, de la Biblia a una realidad.

Ese tipo de ecumenismo diligente, el más fuerte que sigue enriqueciéndose, yo creo que ese tipo de cristianismo va a crear lo que nosotros llamamos el Camino de Jesús, la tradición de Jesús. Más importante que tener iglesias es tener a todos aquellos que tienen dificultades con cualquier iglesia, pero quieren seguir el Camino de Jesús, que es del amor incondicional, de echarse por los pobres, por la justicia, por la paz, eso yo quiero y que acepten al evangelio, acepten a Jesús.

Entonces, hay que subrayar mucho eso, porque inicialmente no había iglesia, había el camino de Jesús, es curioso que los apóstoles llamaban agresi, la agresia de Jesús, porque en griego agresi, agresia es un camino particular, no era doctrinario. Entonces tres veces dice: hay los que siguen la agrise de Jesús, el camino de Jesús, la inspiración de Jesús y eso era lo primero, y seguirá por todos los siglos y hoy más que nunca, ahora que hay un mundo globalizado y todas las iglesias son occidentales, las demás de África, de Asia tienen la dificultad de decir, bueno son iglesias que se han articulado con la colonización, con la dominación del mundo, entonces, carga una sombra sobre ellas. Pero sí dicen el Camino de Jesús.

Yo me he encontrado con muchos que dicen: Jesús no es cristiano, Jesús no es un individuo, porque tiene toda esa compasión, ese karma, que Dios hace crecer a través de la historia, eso creo que tendrá que ver con el tipo de ecumenismo que hay que apoyar, ha quedado abierto, lo importante no es que haya religión ni iglesias, lo importante es que hayan personas sensibles, solidarias, buenas, que luchen, que den su vida para los demás, cultiven la paz porque eso quería Jesús.

Denis Torres: Existe una cierta percepción en sectores cristianos y no cristianos de que la teología de la liberación no es vigente, esto a partir de los cambios que se han dado en América Latina. Desde su punto de vista: ¿Cuál es la vigencia de la teología de la liberación, si no es vigente porque no lo es, si lo es, en qué medida? ¿Qué tipo de aggiornamento necesita?
Leonardo Boff: Yo tengo dificultad de aceptar que la teología de liberación no es vigente, porque es el discurso de nuestros detractores. Si uno va al Foro Social Mundial, una semana antes hacemos el Foro Mundial de la Teología de Liberación y nunca vienen menos de 3 mil personas, de Asia, de Corea, África, Estados Unidos, grandes debates.

En octubre del año pasado hicimos la celebración de 50 años del Vaticano II, 40 años de teología de liberación, vinieron mil teólogos solamente latinoamericanos y muchos jóvenes que hacen tesis, sólo sobre mi teología hay por lo menos 70 - 80 tesis, tesis doctorales, tesis de maestrías.

La Teología de la Liberación es una teología vigente, ¿por qué es vigente? Porque es una teología que nació escuchando el grito del oprimido, del oprimido económico, del oprimido de género, las mujeres, de los indígenas, de afrodescendientes, de todos los que sufren alguna opresión, contra la opresión va la liberación y para nosotros la pregunta era, cómo el cristianismo, con una carga simbólica, porque somos herederos, no de un viejo que murió tranquilo en la cama, sino alguien que fue preso, torturado, ejecutado en la cruz, Jesús, somos herederos de eso, que murió en consecuencia de sus acciones, una política, oponiéndose al imperio, es por eso que predicamos que él murió oponiéndose al imperio. Y la otra, oponiéndose a la opresión religiosa, predicando la libertad, el amor incondicional y entró en conflicto. $Y$ no es que Dios quiso su muerte, Dios quiso su fidelidad, incluso implicando la muerte, si fuera necesaria. Y él aceptó eso y murió por nosotros, un anuncio, una práctica.

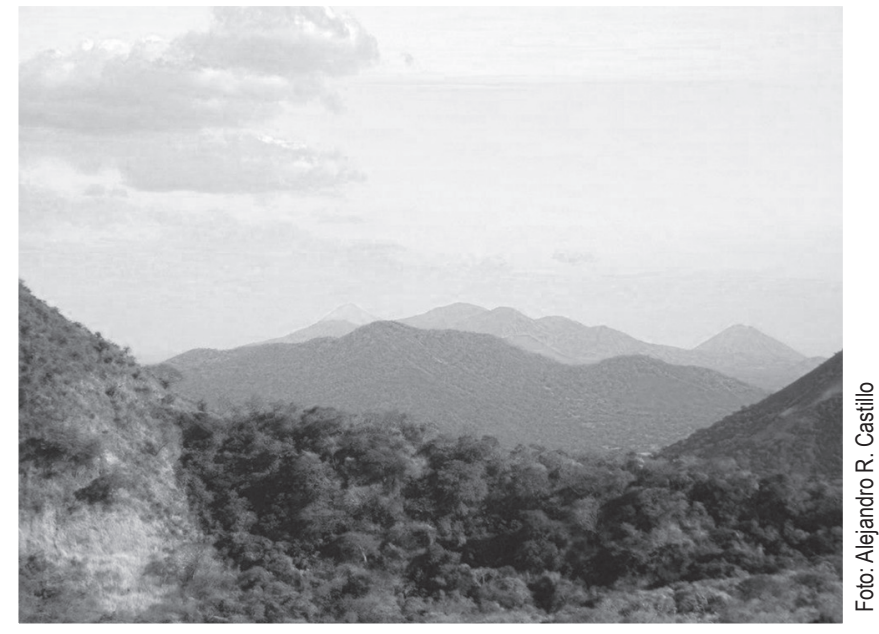


Entonces, la teología de liberación viene escuchando esos gritos y desde la fe dice, el cristianismo puede ayudar junto con otros a que las personas no griten más, porque gritan que les falta vida, les falta la justicia y de ahí es que la marca registrada de la teología de la liberación es la opción por los pobres, contra la pobreza, a favor de la justicia.

Si uno quiere saber si en una parroquia hay teología de liberación. Hay que preguntar: ¿Cómo está la situación de los pobres y qué hace la iglesia? Si no hace nada, ahí no hay teología de liberación. Si dice: no, está organizando a los pobres, para que entren a los sindicatos, para que se organicen, para tener conciencia, es una cosa. La otra, es que no solamente los pobres gritan. A partir de los años 80 s nos hemos dado cuenta, yo fui uno de los primeros que elaboré sobre eso, los pobres gritan, la tierra grita, las aguas gritan, los animales gritan, porque están oprimidos por un tipo de civilización que desbasta la naturaleza, la explota en demasía, entonces, dentro de la opción por los pobres hay que meter al gran pobre, que es el planeta tierra. De ahí nació una fuerte eco-teología de la liberación.

Por otra parte, hay que conceder que no tiene la visibilidad que tenía antes, porque antes era una teología polémica, que estaba en los periódicos todos los días, algo interesante. Hoy no, es algo pacífico y en muchas arquidiócesis de las iglesias, la pastoral común es inspirada por la teología de liberación y algo nuevo, y eso hay que subrayarlo, si uno va a una facultad de teología, no encuentra teología de liberación. Primero, porque el Obispo de Roma ya te pone los profesores y los castigan, les prohíben, y para vergüenza nuestra, la palabra pobre es prohibida dentro de La Curia, la palabra Teología de Liberación, prohibida, no se

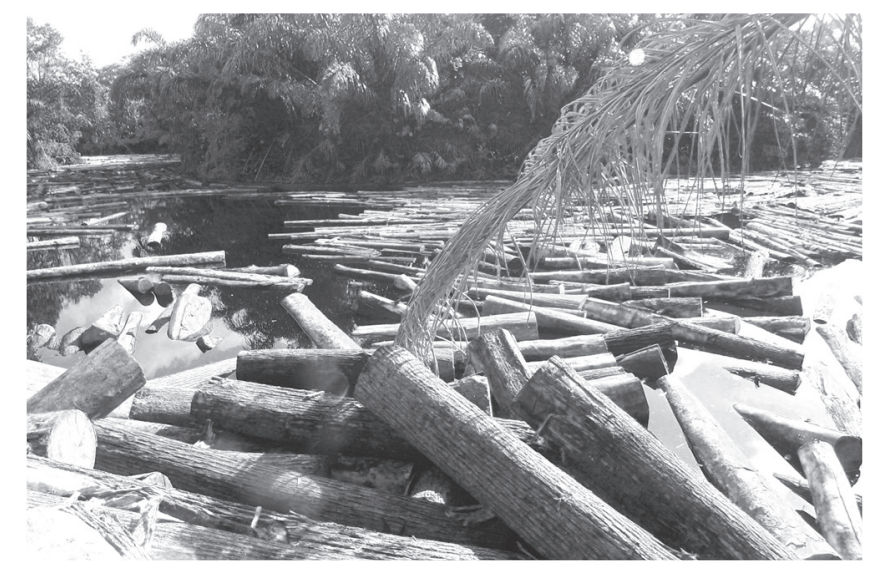

Foto: Manuel Esquivel puede hablar. Y cómo no hablar de pobres, si Jesús fue un pobre, que ha hecho una opción por los pobres, que dijo: "bienaventurados los pobres, ay de vosotros ricos porque tienen miedo de la liberación".

Yo escribí ese libro: "Iglesia, Carisma y Poder", que era el intento de aplicar las intuiciones de la teología de la liberación para relaciones internas de la Iglesia. A Ratzinger no le gustó, me echó un proceso doctrinal, tuve que sentarme en la silla donde se sentó Galileo Galilei y Giordano Bruno, un proceso, "porque la Iglesia no necesita liberación”. ¿Cómo que no? Las mujeres no tienen ciudadanía, los laicos estaban mal, todo centralizado en la iglesia, los derechos humanos difícilmente se respetan, entonces, tiene que liberarse también la iglesia. La liberación tiene que ser integral en la sociedad, también en la Iglesia.

Entonces, ahora, la verdadera teología de liberación está donde siempre debía de estar, que es en los movimientos sociales, que es en la iglesia de la bases. En Brasil hay como 100 mil comunidades de bases, hay más de un millón de círculos bíblicos, si uno frecuenta los círculos, lo que funciona es teología de liberación, que la deriva de la Biblia, Jesús liberador, del hambre, de la enfermedad, del pecado.

Los grandes movimientos sociales en Brasil como los "sin tierras", nacieron en la sacristía de la iglesia. Sus principales personas son agentes de pastorales, que coordinan a nivel nacional, fue casi como en Chile y siempre dicen: yo hice la opción de los pobres no por ser socialista sino por ser franciscano.

Toda la pastoral de los afrodescendientes, de los "sin techo", pastoral indígena, pastoral de los niños, todo es influenciado por la teología de liberación y teología ecuménica y lo bueno es que es ecuménica, porque Roma no puede ahí meter la mano, porque no puede crear problemas con las demás iglesias. Entonces ahí es una teología muy floreciente y tiene sus teólogos, tiene sus casas, sus textos. Entonces, hay que mirar ese tipo de teología que está en las bases de la sociedad, donde los más pobres están. Ahí se vive un cristianismo de liberación, en la iglesia de las bases de la sociedad.

Denis Torres: ¿Por qué se da la Iglesia Popular, es pertinente apostar a ese proyecto?¿Cuál es el papel actual de los cristianos, en particular en aquellos países donde existen proyectos, que algunos caracterizan de progresistas? ¿Cómo se entiende el papel profético del cristiano actualmente? 
Leonardo Boff: Esa es una expresión que no le gusta a Roma ni a la Iglesia, porqueconsideran a la Iglesia Popular una decadencia con la iglesia cristiana, pero existe el hecho que no se puede negar, existe una vasta red de comunidades de bases, pastorales sociales de todo tipo, círculos bíblicos, hemos visto más de un millón en Brasil.

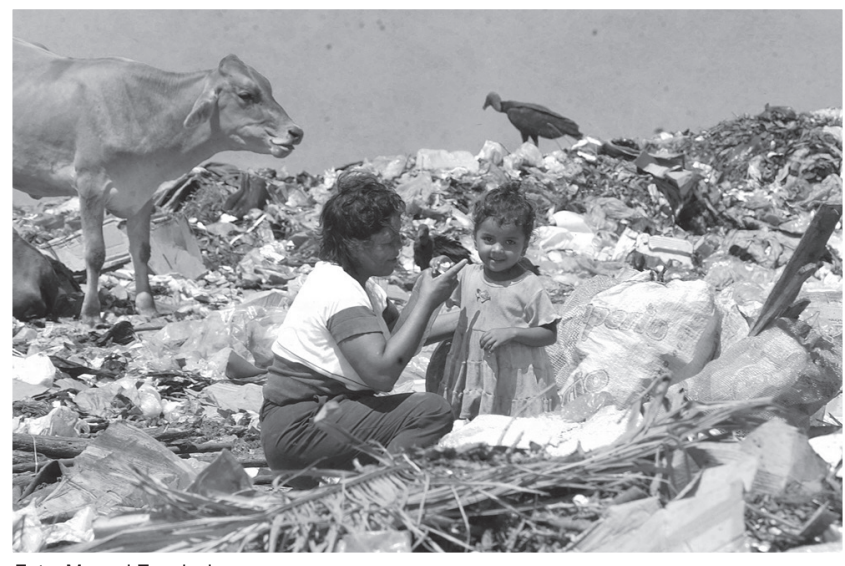

Foto: Manuel Esquivel su cuenta otra forma de repartición de las tierras, una producción más colectiva, comunitaria, reforzar esa cultura popular que ha creado un ambiente de orden religioso, la Iglesia Popular y las religiones populares.

\section{Denis Torres: La} tentación autoritaria y la corrupción son fenómenos que

generalmente acompañan al poder, fundamentalmente ahí donde no existe la vivencia de una plena democracia, incluso en Brasil se están llevando procesos por corrupción a cuadros del PT ¿Qué comentarios nos brindaría Usted sobre esto y cuál es el papel de los cristianos?

Leonardo Boff: Yo creo que todos los países que fueron un día colonias, han incorporado mecanismos de corrupción, porque los dominados tenían que encontrar caminos, escaparse de la dominación, entonces, corrompían a los dueños, se corrompían, entonces la corrupción es un dato de las políticas latinoamericanas. Y por otra parte, mucho de la corrupción que se atribuye al PT, son hechos de corrupción anteriores que el PPA desenmascaró y ha mostrado la corrupción. No es que fue el PT el corrupto sino los gobiernos anteriores, pero nadie había desenmascarado eso, y él creó todo un mecanismo de jueces, estructura de juristas para, de arriba abajo desenmascarar todo el mecanismo de corrupción, pero eso no ha impedido, hay que reconocerlo, que grupos del PT y grupos centrales desde la casa la Casa Civil, se han dejado corromper y las causas principales de esto, es porque han perdido conexión con las bases populares y eso se puede establecer como ley.

Cuando un político pierde su conexión orgánica con la base que lo sustenta, divide la política, palaciana, la política del parlamento, negociaciones, tráfico de influencias, acaban corruptos. Cuando van al pueblo, el pueblo les cobra y ven la dolencia del pueblo, los sacrificios, las luchas, se conmueven y dicen no, tengo que ayudarles. Pero cuando se alejan, el pueblo es un concepto, ya no es una realidad que va en la piel y efectivamente se han corrompido, pero es 
una corrupción diferente de las clásicas corrupciones porque en las clásicas corrupciones era que uno debía tener una ventaja personal, hacerse rico. El PT no, ninguno de ellos se corrompió en función de algo personal, pero se corrompió para crear un fondo tan grande, para que el partido ganara por 20 años todas las elecciones en el municipio, el estado y la nación, y esa es una forma de corrupción porque daña la democracia, entonces es corrupto y la corrupción es corporativa, le interesa al partido.

Entonces yo creo y eso el clásico del poder que es Hobbes, el del Leviatán, que es un Tratado del poder y él dice implícitamente: yo me doy cuenta que en los seres humanos hay una tendencia irrefrenable, constante, que solamente termina con la muerte, de querer poder y más poder y el poder solamente se asegura aliándose a otros poderes y aumentando su poder, porque un poder débil no existe, tiene que ser un poder fuerte.

Entonces, en la dinámica del poder, si uno no tiene una dimensión ética le altera el poder, con desviación de la soberanía popular, el poder como instrumento para someter, tener privilegios, allí uno escoge. Y he ahí la famosa frase de Lord Acton, que el absoluto poder, corrompe absolutamente. ¿Y en qué contexto lo dice? Él era profesor de historia en Cambridge, que se especializó en el poder de los Cardenales renacentistas, que han llevado el poder al máximo, entonces él les dice: el absoluto poder de los Cardenales lleva a la absoluta corrupción, de ahí han inventado el nepotismo que es una invención de los Cardenales, de los Papas. Es una corrupción vergonzosa de toda la Iglesia renacentista.

\section{Entonces yo creo que no hay que satanizar el poder, pero, si el poder no es rotativo, si el poder no es vigilado, el poder va a querer mantenerse como poder y ahí se} corrompe. Creo que hay que tener un sentido democrático del poder, un sentido ético y quien no tiene un sentido ético, ya sea del poder como instrumento sino como fin en sí mismo, acaba en la corrupción. Sea cristiano, sea político, sea uno de la economía, es la lógica del poder, poco importa el signo bajo el cual viene. Es por eso que Jesús dice, los grandes de este mundo dominan, con nosotros no será así, que cuando sufres las tentaciones, las tres tentaciones del poder, exactamente se vuelve más débil: el poder profético de transformar piedra en pan, el poder político de dominar a las naciones y el poder sacerdotal del templo para hacer las grandes reformas morales y Jesús rechazó los tres poderes, como algo diabólico, algo que viene del diablo. Entonces si no hacemos una terapia del poder él termina en su forma diabólica.

Denis Torres: Hay un poeta nuestro que dice: Cristo encarna la negación del poder, Trostky la caída del poder, el Che la renuncia del poder iEl cristiano debe tener alguna dosis de ácrata una vez que concibe una determinada caracterización de un proyecto, de cara a comprometerse incondicionalmente o mantener un acompañamiento crítico?

Leonardo Boff: Yo cuando hablo a grupos de bases, a líderes de comunidades, de niveles sociales siempre les digo: nosotros queremos el poder y queremos alcanzarlo para con el poder hacer transformaciones sociales sustantivas. Necesitamos poder, pero un poder como servicio a una causa más grande, no poder como automagnificación y como segundo les digo: si no hacemos eso, en donde hay poder desaparece el amor y la misericordia, y cuando hay amor y misericordia allí no hay voluntad de poder.

Entonces, hay que superar esa visión católica de humildad, "nosotros no queremos poder, queremos solo servicio, queremos estar allí a mano de otro...", ante ellos les digo: no, queremos poder sí, político, poder económico, si se puede. ¿Para qué? No para nosotros sino para hacer reformas que no se hacen de otra manera, sino ocupando el lugar de poder y utilizar ese poder en beneficio del pueblo, que es el portador primero de la soberanía popular, portador del poder. 


\section{Integridad de la Creación}

Denis Torres: La destrucción de la biosfera en nuestros tiempos ha llegado a límites pavorosos asumiendo la forma de genocidio y suicidio masivo. ¿Hay esperanza de salvar nuestro planeta, que les diría Usted a esas voces apocalípticas que indican que es demasiado tarde? ¿Es posible pensar que Dios permite la destrucción de su propia creación?

Leonardo Boff: Creo que mientras sigan la cultura del capital, una cultura del consumismo que lo acompaña, no vamos a salvar al planeta. Vamos al encuentro de una gran catástrofe ecológica-social, incluso, con el riesgo del desaparecimiento de la especie humana y del sistema vivo.

La tierra seguirá, aún cubierta de cadáveres, porque la tierra no necesita de nosotros, nosotros necesitamos de la tierra. Si mientras, no superamos históricamente el capitalismo: ¿Por qué? ¿Cuál es la lógica del capitalismo? Es la acumulación ilimitada que implica la degradación de la naturaleza y una doble injusticia: la injusticia social creando grandes desigualdades, grandes pobrezas en una parte y gran acumulación en otra y una injusticia ecológica, que es desforestando, contaminando el suelo, las aguas, destruyendo ecosistemas. Entonces, al seguir esa lógica, no tendremos salvación, porque la tierra no aguanta. Ahora, ya, la tierra para reponer lo que le sacamos en un año, necesita un año y medio, entonces hemos pasado ya el $30 \%$ de su capacidad de vitalidad.

La tierra está ya enferma porque la hemos explotado demasiado, todas las señales están en rojo, la cuenta, todo está totalmente en rojo. Entonces, yo creo que allí se impone una alternativa: o cambiamos o morimos y eso no es algo apocalíptico, es algo que los grandes científicos nos dan como datos. Por ejemplo, sólo un dato que es significativo, del más grande biólogo del mundo que es Edward Wilson de Harvard, donde en su último libro: "Futuro de la vida" y en otro: "Cómo salvar la vida del planeta", pone como dato reciente hace pocos meses, que dada la agresividad del sistema industrialista que utiliza tecnologías cada vez más refinadas, más sutiles, estamos destruyendo al año entre 70 a 100 mil especies de organismos vivos que desaparecen definitivamente, esa es una devastación.

Estamos llevando una guerra total contra Gaia y no hay ninguna certeza de que vamos a ganar esa guerra, porque la tierra es mucho más fuerte que nosotros. Por otra parte, hay que decir que tenemos que producir para atender demandas humanas y no solamente las nuestras sino de los árboles, de los animales, ellos también necesitan de la biosfera, ellos también fueron creados por la Madre Tierra, entonces, tenemos que producir, pero tenemos que producir en la línea del buen vivir de los pueblos, de buscar el equilibrio. El equilibrio, cuánto este ecosistema nos puede dar, reconocer sus límites, respetarlos, respetar los límites de la Madre Tierra, no saquearla más porque necesitamos de ella.

Es una cultura de la sobriedad compartida, de la sencillez asumida y no de la acumulación tremenda donde 327 familias, grupos de ricos, pluri-ricos del mundo poseen más rentas que 45 países donde viven 600 millones de personas. El 1\% de los ricos posee el $60 \%$ de toda la riqueza de la tierra. Esa es una injusticia que grita al cielo. Entonces, la tierra tiene mucha capacidad de soportar, pero puede llegar un momento en que dice: no quiero más acoger a éstos, porque son demasiados agresivos y muy dañinos y todo lo demás. Pero no es la humanidad la que ha hecho eso, ha sido ese pequeño tercio de la humanidad que tiene todo el poder, todo el saber, toda la economía en las manos y que busca solamente sus privilegios, su vida y desprecian todo lo demás y que a esa destrucción le llaman: las externalidades, el efecto no intencionado, que hace polución del agua, del aire, de los suelos.

Creo que la humanidad tiene que defenderse contra esos asesinos y no tenemos mucho tiempo, y allí yo creo que tenemos que reconocer y es algo un poco incluso misterioso, algo de la tierra y uno lo siente eso, participando en los foros sociales mundiales, los centenares que van allí, no es tanto para escuchar charlas, es para intercambiar, de cómo tratar mejor las

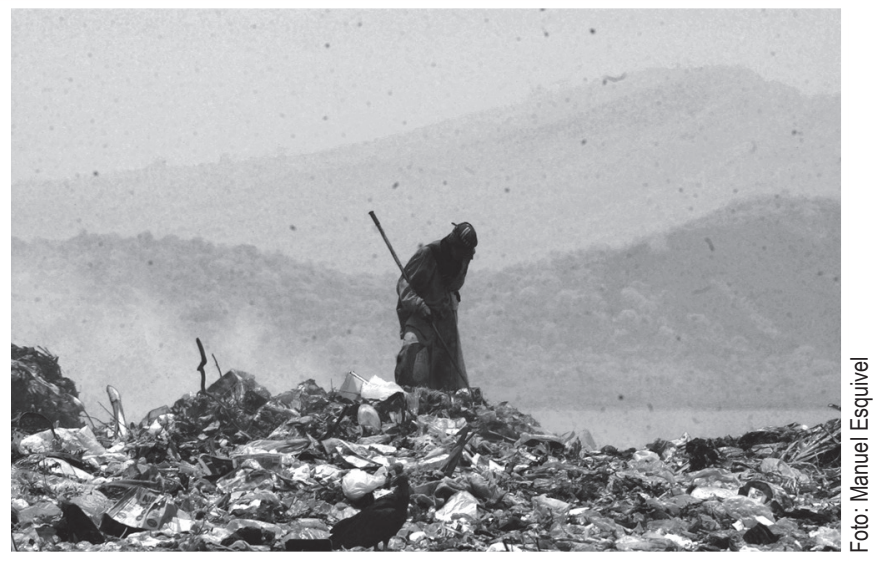


semillas, cómo tratar mejor el agua, como construir con otros materiales, mil maneras de experiencias y por todas las partes emerge la conciencia de nuestra responsabilidad colectiva, que tenemos que salvar, no la tierra, la vitalidad de la tierra sino salvar la vida, la vida si está amenazada.

Salvar nuestra civilización que la hemos construido en centenares de miles de años y de duro trabajo, todos los pueblos han creado nuestra civilización con su arte, su belleza, como se ve aquí en la casa de Miguel d' Escoto.

Todos vivimos un momento dramático, como nunca lo hemos vivido antes, es decir, hemos creado una máquina de muerte que nos puede destruir a todos sin salvarse nadie, nunca antes ocurrió esto. Ahora, tenemos ya construidas armas químicas, biológicas, nucleares, que pueden poner fin a ese experimento humano.

Pero, yo creo personalmente, pensando en el proceso de evolución porque, conociendo un poco la historia de la tierra, la tierra ha pasado por 15 grandes diezmaciones y en dos de ellas perdió casi el 90\% del capital biológico, pero se rehízo, se demoró 10 millones de años, la última grande, cuando desaparecieron los dinosaurios hace ya 65 millones de años, la tierra necesitó 1 millón de años para rehacerse y allí vino una nueva floración de vida como nunca y apareció también el ser humano.

Creo que la vida, y lo dice Edward Wilson, la vida no es ni material ni espiritual, la vida es eterna. Nadie ha conseguido exterminar la vida. Y dice en tono de broma: la vida es una especie de plaga que cayó en este planeta y que nadie consigue destruirla, esta siempre se rehace de alguna manera. Entonces, yo creo que el problema es más bien la vida humana, que es consciente, que le han dejado al universo y se siente seguro y allí yo creo que hay que pensarlo también en la dimensión teológica, porque la evolución ha creado la religión, ha creado las teologías, ha creado todo lo que existe.

\section{Hay un texto bellísimo del libro de la Sabiduría, el capítulo 11, versículo 26, que dice: "Señor, tu creaste a todos los seres. Tú amas a todos los seres que creaste y no odias a ninguno. $Y$ tú los amas porque eres el soberano amante de la vida”. Entonces,}
Dios que es soberano amante de la vida, no va a permitir que esa vida sea destruida, va a crear un tipo de inteligencia, un tsunami de conciencia donde los seres humanos se despierten y digan: qué tontos somos, qué estúpidos somos para liquidar esta belleza de la Amazonía, la belleza de Nicaragua ¿Por qué vamos a destrozarla? Y vamos a hacer de todo para salvarla, rescatarla y vivir en paz con la tierra, no solamente entre nosotros.

Y allí salvaremos, pasaremos de una tragedia anunciada, por una gran crisis, la crisis de la purificación, positiva, que implica un salto de calidad en dirección a una sociedad más sensible, biocentrada, donde el centro es vida, vida humana, vida de la tierra, Gaia, la economía y la política al servicio de la vida. Y esa es mi esperanza, creo que eso va a triunfar.

Denis Torres: ¿Es posible sostener aún la visión de fraternidad cósmica frente a los graves problemas ecológicos mundiales, en esto ayuda la Carta de la Tierra?

Leonardo Boff: Hay un dato de ciencia que nos ayuda a entender eso. Cuando en 1952, Crick y Watson han descodificado el código genético, se han dado cuenta de algo espantoso que algunos consideran el invento más grande de los tiempos. Se han dado cuenta que todos los seres vivos, desde la bacteria más originaria, pasando por las grandes florestas, los dinosaurios, los colibrís, llegando a nosotros, todos los seres vivos tienen los mismos 20 aminoácidos, las mismas 4 bases fosfatadas, aquellas bases que permiten las conexiones entre los aminoácidos. Entonces todos somos parientes, todos somos hermanos y hermanas, todos formamos la gran comunidad cósmica.

Lo que la Carta de la Tierra manifiesta es el parentesco universal con todos los seres, entonces, existe con hechos de ciencia, hechos de realidad, que somos efectivamente hermanos de esta agua, de estos rios, hermanos de las hojas, porque tenemos los mismos ladrillos que construyen el edificio de la vida, los tenemos todos, hay una fraternidad. El problema es que no lo hemos internalizado subjetivamente, como conciencia. San Francisco lo ha hecho por intuición, llamaba a todos los seres por el dulce nombre de 
hermano y hermana, todos lo sabemos por el lado de la ciencia, entonces, somos hermanos. A los hermanos hay que tratarlos con cariño, humildad, amistad, con amor. Y si consideramos que todos somos hermanos y hermanas... ¿Por qué no cuidarnos como realmente hermanos y hermanas?

Entonces, eso es verdad, pero la cultura nuestra no crea ninguna condición para que eso se pueda vivir, porque el eje estructural de esa cultura es el libre mercado de la economía que es la competición. La competición es hacer guerra de todos contra todos y allí se quiebran los lazos de fraternidad, pero sabemos también por la cosmología, la etnobiologia, que la energía más fuerte, que la ley más universal en el universo no es esa de Darwin, que la victoria es del más hábil, el más fuerte, sino que es la cooperación de todos con todos, para que todos se ayuden mutuamente, todos puedan convivir para que se mantenga la gran biodiversidad, entonces, nosotros somos esencialmente seres de cooperación.

Aristóteles lo dice de otra manera: somos seres políticos. Y ser políticos significa que somos seres de convivencia y que establecemos un contrato social entre nosotros. Entonces, somos seres de fraternidad y al internalizar esto, al hacer de eso un proyecto de vida, tiene como consecuencia la gran paz entre los seres humanos, porque no tenemos razón para agredirnos, para ofendernos, porque somos hermanos y hermanas de una gran familia, histórica, terrenal, la gran familia humana.

Denis Torres: Usted y el Padre d' Escoto apoyados por otros especialistas $y$ pensadores, han echado andar la iniciativa de una Carta de los Derechos de la Humanidad y la Madre Tierra. ¿Cuál es el impacto de esta propuesta en la sociedad y en los estados del mundo?
Leonado Boff: Esa visión supone una otra cosmología, es decir, supone otra lectura de la realidad, porque la lectura común nos viene de los clásicos, los europeos, Newton, Francis Bacon, Descartes, que ven la tierra como algo que está allí, sin inteligencia, algo muerto y nosotros como señores y dueños de la naturaleza, estamos por encima y haciendo lo que queremos de la tierra, entonces, ni se podía pensar en los derechos de la tierra, la tierra es el campo de ejercicio de mi libertad, de la explotación, sacar las riquezas.

Pero, con la evolución de la astrofísica, de la nueva biología, de la cosmología, que permite más una visión integrada, nos hemos dado cuenta que la tierra no es algo muerto, que la tierra es un súper organismo vivo que articula lo físico, lo biológico, lo químico, lo ecológico, de tal manera que siempre produce vida. A millones de millones de años siempre tiene el $21 \%$ de oxigeno, si tuviera $15 \%$ nos desmayaríamos todos, si subiera a $25 \%$ nadie podría encender nada porque se quemaría todo.

La salinización de los océanos, a millones, mil millones de años, es $3,4 \%$, si subiera al $6 \%$ sería imposible la vida, si se cayera a $2 \%$ sería como el mar muerto, siempre mantiene su equilibrio. Así, todos los elementos que los científicos han podido identificar $\mathrm{y}$ han dicho: la tierra no solamente tiene vida sobre ella, ella misma es vida. Vive.

\section{La Carta de la} Tierra contiene eso, la tierra, la tierra viva, que genera todo lo que necesitamos para vivir. Entonces, la tierra es vida y si el ser humano es aquella porción de la tierra que en el proceso de evolución llegó a un alto grado de complejidad, de interioridad y de orden más alto; si nosotros somos aquella porción de 
la tierra compleja, es la porción que siente, que piensa, que ama, que cuida.

Nosotros somos tierra. Por eso hombre viene de humus, humus es tierra, tierra fértil, tierra fecunda, como dice el gran cantante argentino, indígena y poeta, Atahualpa Yupanqui: el ser humano es la tierra que anda, la tierra que piensa, la tierra que ama, la tierra que canta. Somos tierra. Entonces, nosotros y eso nadie lo puede negar, tenemos derechos, la Declaración de los Derechos Humanos garantiza todos, entonces... ¿Por qué no, nuestra Madre Tierra, de dónde venimos, no tiene derechos si ella también es vida? La tierra tiene derecho de ser respetada, de tener su sangre pura, que son los ríos, de tener sus cabellos bellos, que son las forestas, tener su cuerpo sano con todas las partes verdes de la naturaleza.

La tierra tiene derechos y todos los seres de la tierra tienen derechos porque tienen un valor intrínseco, valen por sí mismo, más allá de la utilización posible que puede tener el ser humano, tiene un valor en sí mismo, revela algo del universo, es un mensaje del Creador, todos tienen derechos, por eso es que nuestra democracia, no puede ser antropocéntrica, solo democracia de los humanos, tiene que ser la democracia socio cósmica, porque hay otros ciudadanos.

¿Qué sería de Managua si no tuviera lagos, si no tuviera árboles, si no tuviera los pájaros que están cantando aquí, si no tuviera animales? Todos pertenecen a esta gran familia y tienen sus derechos de ser respetados y alimentados. Entonces, tenemos que caminar a la dirección de una democracia sociocósmica, donde todos los seres son involucrados, son respetados, participan en nuestro destino y eso yo creo que no va a tardar mucho que la humanidad pueda darse cuenta de eso, porque los tiempos urgen, son rápidos y tenemos que tomar ya ahora decisiones importantes para garantizar el futuro.

Denis Torres: ¿Y frente a esta situación cuál es la posición de los cristianos? Concretamente frente a la problemática de la violencia contra la Creación.

Leonardo Boff: Yo creo que hay que reconocer que los cristianos y las demás iglesias son cómplices de la situación actual mundial y sí hubo algo equivocado, hubo un error en esta evangelización, por no incluir la tierra, por no incluir el hecho que está claro en Génesis 2, que el ser humano fue puesto en el Jardín del Edén para cuidar, para guardar, para proteger. No hemos predicado eso, más bien "el ser humano es rey y reino de la Creación"; y eso es mentira, cuando todo estaba listo, 99.98\% estaba listo, allí emergió el ser humano, entonces, la tierra no ha tenido necesidad de nosotros para tener esa inmensa biodiversidad, esa belleza extraordinaria, si nosotros aparecimos tan tarde es para cuidar de todo eso, tener responsabilidad ética, por eso tenemos inteligencia, mirar las cosas, favorecer a los más débiles, darles chance de sobrevivir.

Yo creo que la iglesia, las iglesias y religiones son cómplices de la crisis, pero tenemos un deber ahora, con el capital religioso que tenemos, de dar un aporte muy importante. Yo creo que es un aporte pedagógico, de enseñar, por ejemplo: lo que más hace falta en el mundo de hoy es el respeto a la naturaleza, cuidar las generaciones.

Nosotros predicamos el respeto a la ostia consagrada, respeto al Libro Sagrado, respeto a los santos. Esa misma actitud hay que llevarla a cada ser de la Creación, como San Francisco, que no pisaba sobre las piedras, porque decía: Jesús fue llamado piedra, cuando veía una hormiguita en el camino la sacaba para que no fuera pisada. Esa reverencia, ese cuidado, ese amor con todas las cosas, no solamente los objetos sagrados sino las cosas, todas, que forman el templo de Dios.

Esa pedagogía de la iglesia tiene que meterla en la cabeza de cada cristiano, para que sea un agente ecológico de respeto, de protección, de salvaguardia de todo lo creado y curiosamente Edward Wilson, el más grande biólogo del mundo, su último libro es: Creación, subtitulo: ¿Cómo salvar la vida en el planeta? Él escribe una carta a un pastor protestante, diciendo: tenemos que hacer una alianza sagrada entre dos grandes poderes que él considera los más fuertes, el poder de la tecno-ciencia, que puede cambiar el mundo, así como puede destruir el mundo, y el poder de las religiones que mueve corazones, y que tiene valores, pero también puede hacer que una persona se haga una persona "bomba".

$$
\begin{aligned}
& \text { Tenemos que hacer una alianza sagrada } \\
& \text { entre religión y tecno-ciencia, la religión va } \\
& \text { a enseñar a la ciencia, que sea hecho con } \\
& \text { conciencia, en función no del mercado, sí en } \\
& \text { función de la vida y la ciencia va a decirle a } \\
& \text { la religión que no sea tan fundamentalista, }
\end{aligned}
$$


que no se quede solo en la escritura y en los santos y en la Biblia y en la ostia consagrada, sino que venere, respete todo, una ayudando a la otra.

Si esa alianza sagrada no va a triunfar, me temo el fin de la especie, termina: yo que soy ateo, estoy rezando para que esa alianza sagrada se dé: tener cultura orgánica, familiar, maneras más artesanales de existir, rescatando viejas experiencias humanas que hemos olvidado y de repente se hacen actuales, porque nos salvan de necesidades y nos ayudan a salir de esa dictadura del capital, del pensamiento único del sistema que quiere solamente acumular ganancias a precio de poner en gran estrés a toda la naturaleza.

Entonces, yo creo que vamos lentamente en la dirección de otro tipo de producción que en el fondo tendrá como preocupación la sustentación de toda vida ¿Cómo pasar de una cultura realista a una cultura de la sustentación de todo tipo de vida? ¿Eso podemos hacerlo? No podemos, ¡Tenemos que hacerlo! La condición es no sacrificar los recursos.

\section{Un nuevo orden mundial}

Denis Torres: La temática de las Naciones Unidas hasta ahora ha sido una temática enclaustrada en la academia en los ámbitos de especialización, en las cancillerías. Cuando se plantea una reinvención, una transformación profunda en las Naciones Unidas... ¿No es acaso necesario sacar esta temática que nos atinge a todos los seres humano a la calle, al movimiento social, a la sociedad civil, levantarla como una bandera de todos, no sólo un debate académico-político? ¿Qué opina usted?

Leonado Boff: Yo creo que hay que partir de esto, la ONU es el gran instrumento del imperialismo, de las potencias superiores, victoriosas de la Segunda Guerra que tienen derecho a veto. No pasa nada que no es de interés del imperialismo, especialmente Estados Unidos no le da ninguna importancia y si se le ocurre votar a favor, lo hace, sino pasa por encima como Bush con la guerra contra Irak. Entonces es una institución que nació ya fracasada, porque no sirve a la paz mundial ni al desarrollo colectivo, sirve a los grandes intereses de cuatro o cinco naciones.

Ha perdido respetabilidad, no tiene mucha importancia. Por otra parte, es importante porque es uno de los pocos lugares donde los jefes de estado del mundo entero, 192, pueden encontrarse en este momento, pueden discutir, saben que no tendrá ninguna consecuencia, pero se encuentran.

Creo que Miguel d' Escoto tuvo una idea genial, una inspiración que es de magnitud histórica, de una refundación de la ONU, la ONU de la humanidad, la ONU de los pueblos, no solamente la ONU de los gobiernos, también de los pueblos. Eso supone la gobernabilidad de toda la tierra, porque llegamos a un punto en que algunos problemas son globales y exigen una solución global y para eso tienen que tener una instancia que analice, que discuta, que decida, que es la reinvención de la ONU, bajo otra inspiración donde el eje central no son los poderes, ni siquiera el desarrollo, sí la preservación de los derechos de la Madre Tierra, de la Humanidad.

Si preservamos esos derechos, entonces no necesitamos hablar de sustentabilidad, ni de cultura de paz, porque si respetamos los bienes de la tierra, el bien común de la tierra, lo que hace que la tierra viva, y que la humanidad se siente como especie, como una gran familia, que se sienta alrededor de la mesa, la gran comenzalidad de los pueblos, y ese es el eje central, ideológico, de la nueva Carta y tiene una parte más estructural: los tribunales contra crímenes contra la humanidad, crímenes contra la naturaleza; la descentralización del sistema financiero, no centralizando como el FMI, el Banco Mundial sino bancos regionales que atienden las necesidades de cada región.

Entonces, es un gran ideal que las potencias no aceptan, pero tiene que empezar de abajo y ya tiene de muchos países el apoyo incluso, de un grande como China y otros que dicen: de verdad tenemos que pensar en el futuro de la humanidad, en la gobernanza global, una ONU diferente, porque cuando nos lleguen las grandes crisis, estaremos sin saber qué hacer, no tenemos los instrumentos de articulación, entonces hay que prepararnos ahora. 
Yo creo que es urgente que se discuta en las calles, en las universidades, que se rechace la ONU, que el Centro no esté ni siquiera en Estados Unidos, esté en África, fuera de los grandes conflictos. Todos los pueblos pueden reunirse para pensar el futuro común de la tierra y de la humanidad. Y tenemos que hacerlo porque si no hacemos eso, vamos al encuentro de un conflicto generalizado, previsible, cuyo final puede ser dramático.

\section{IV. ¿Una nueva espiritualidad?}

Denis Torres: Frente a la ausencia de valores religiosos y considerando las iniquidades del capitalismo materialista (privado o estatal)... ¿Cree Usted que la espiritualidad religiosa es una necesidad para el ser humano contemporáneo? ¿Hemos mutado tanto que somos capaces de prescindir de la espiritualidad?

Leonardo Boff: Creo que la iglesia es una de las instituciones, como las religiones, la religión budista, andinas, las grandes religiones que tienen un profundo sentido de unión con la tierra, son culturas espirituales. No se concibe una secularización sin sentir la Pacha Mama, sentir un espíritu bueno de las montañas, de las aguas. Entonces, yo creo que la iglesia puede ser una fuente de paz y reconciliación, pero algunas veces una fuente de guerra, porque las religiones abrahámicas, judíos, cristianos y musulmanes, fueron los que más han creado guerras en el mundo. Entonces es un poco contradictorio, pero eso lo han hecho contra su propia naturaleza, porque su naturaleza es crear paz, concordia, reconocimiento, perdón, aceptación hasta del enemigo. Si uno vive eso, vive una paz perenne, una paz perpetua, una paz que tiene su última raíz en el Dios vivo.

Denis Torres: Padre, quisiéramos que en su próximo paso por Nicaragua tener el honor de un encuentro con Usted en nuestra Universidad e Instituto "Martin Luther King" para profundizar sobre estos y otros temas de interés para la humanidad.

Leonardo Boff: Cuenten conmigo, será también un honor el seguir compartiendo con ustedes.

Denis Torres: Muchas Gracias.

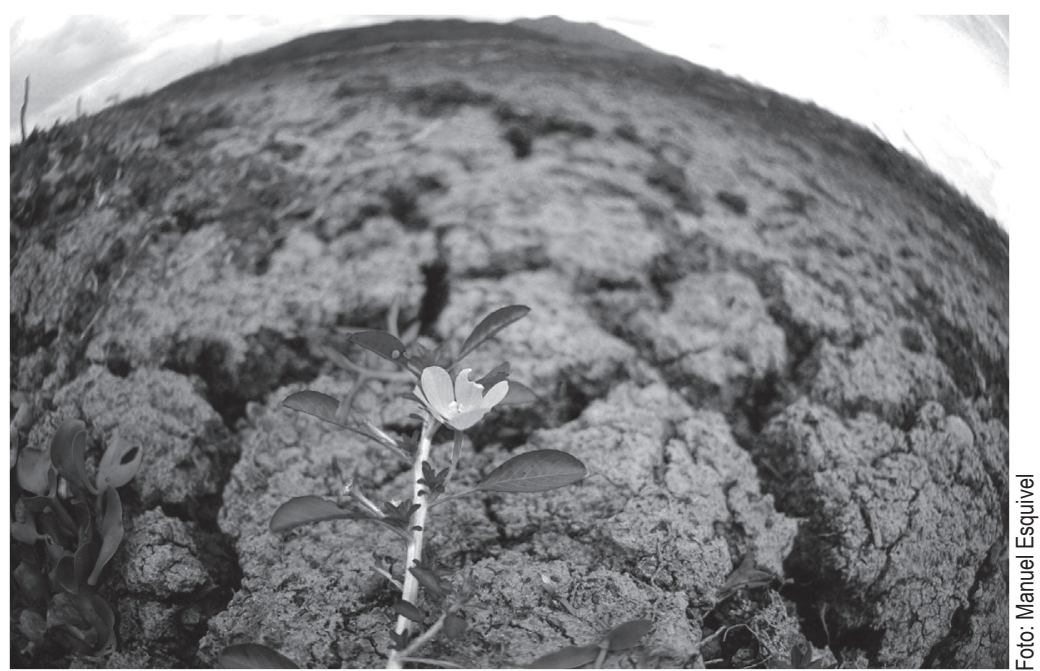

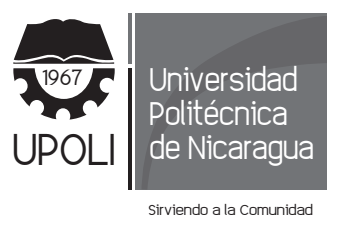

Sirviendo a la Comunidad
Intituto "Martin Luther King"

Universidad Politécnica de Nicaragua (UPOLI)

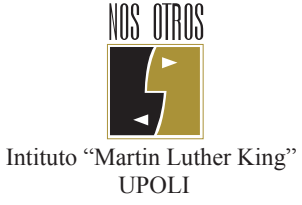

